\title{
Het Wetsvoorstel Spoedwet KEI: een verruiming van regie van de rechter en de mogelijkheden rondom de mondelinge behandeling?
}

\author{
Pauline Ernste $e^{*}$
}

\section{Inleiding}

Op 26 maart 2019 is bij de Tweede Kamer het wetsvoorstel ingediend tot intrekking van de verplichting tot digitaal procederen bij de rechtbanken Gelderland en Midden-Nederland én tot verruiming van de mogelijkheden van de mondelinge behandeling in het civiele procesrecht (hierna: het Wetsvoorstel Spoedwet KEI). ${ }^{1}$ Dit wetsvoorstel is het vervolg op een aantal wetten ${ }^{2}$ en besluiten tot vereenvoudiging en digitalisering van het procesrecht van het Programma Kwaliteit en Innovatie (KEI), dat door het parlement in 2016 is aanvaard en in het Staatsblad is gepubliceerd (hierna: de Wetgeving van 2016). ${ }^{3}$ Met deze wetgeving beoogde de wetgever vereenvoudiging en versnelling van de procedure door de invoering van een uniforme procedure, waarin de rechter middelen heeft om een vlot verloop van de procedure te bewerkstelligen en waarin wettelijke termijnen gelden voor het verrichten van proceshandelingen door partijen en voor het doen van uitspraak door de rechter. De wijzigingen hebben tot doel de civiele procedure overzichtelijker en meer voorspelbaar te maken, waardoor het schriftelijke gedeelte van de civiele procedure kan worden gedigitaliseerd. ${ }^{4}$ In het vervolg van deze bijdrage duid ik bepalingen uit de Wetgeving van 2016, die voor alle civiele procedures in werking zijn getreden, aan als 'art. ... Rv', bepalingen uit de Wetgeving van 2016 die niet, nog niet, of niet voor alle procedures in werking zijn getreden als 'art. ... Rv KEI' en bepalingen uit het Wetsvoorstel Spoedwet KEI als 'art. ... Rv Spoedwet'.

\footnotetext{
* Mw. mr. P.E. Ernste is advocaat bij NautaDutilh te Amsterdam en onderzoeker bij het Onderzoekcentrum Onderneming \& Recht van de Radboud Universiteit Nijmegen.

1. Zie voor de tekst van dit wetsvoorstel: Kamerstukken II 2018/19, 35175, 2 (te raadplegen via https://zoek.officielebekendmakingen.nl/kst $-35175-2 . h t m l)$.

2. Zie Wet vereenvoudiging en digitalisering van het procesrecht (Kamerstuknummer 34059) en Wet digitalisering van hoger beroep en cassatie (Kamerstuknummer 34138).

3. Zie Stb. 2016, 288-294.

4. Zie Kamerstukken II 2014/15, 34059, 3, p. 1-2; Kamerstukken II 2014/15, 34212, 3, p. 1-2.
}

In 2017 is een begin gemaakt met de gefaseerde invoering van de Wetgeving van 2016. Bij de Hoge Raad is invoering van deze wetgeving en de digitalisering van de vorderingsprocedure per 1 maart 2017 soepel verlopen en uit de evaluatie uit 2017 blijkt dat het digitale systeem door advocaten wordt gewaardeerd om zijn betrouwbaarheid, gebruiksgemak en snelheid. ${ }^{5}$ Per 1 september 2017 is de Wetgeving van 2016 ook in werking getreden voor handelszaken bij de rechtbanken Gelderland en Midden-Nederland. ${ }^{6}$ Uit de verplichte pilot bij deze rechtbanken is echter gebleken dat de schaal en complexiteit van het digitaliseringsproces zijn onderschat. Om deze reden wordt het digitale systeem niet verder uitgerold bij andere rechtbanken, maar is ervoor gekozen om de digitalisering op andere wijze vorm te geven. ${ }^{7}$ De wetgever wil, gezien het spoedeisend belang van de rechtspraak om het civiele procesrecht bij alle rechtbanken weer uniform te laten gelden, op de kortst mogelijke termijn de verplichting tot digitale indiening bij de rechtbanken Gelderland en Midden-Nederland beëindigen. Hiervoor is nodig dat de Wetgeving van 2016, op basis waarvan bij deze twee rechtbanken digitaal wordt geprocedeerd, voor deze twee rechtbanken wordt ingetrokken (denk onder andere aan art. 30a-30o, art. 30q en art. 111-125 Rv KEI). De wetgever heeft daarom op 26 maart 2019 bij de Tweede Kamer het hiervoor genoemde wetsvoorstel ingediend en daarbij gekozen voor spoedwetgeving. ${ }^{8}$ Het Wetsvoorstel Spoedwet KEI treedt per 1 oktober 2019 in werking (Stb. 2019, 247). Bij de Hoge Raad blijven de bepalingen van de

5. Zie het Jaarverslag 2017 van de Hoge Raad (te raadplegen via www rechtspraak.nl).

6. Enkele bepalingen zijn reeds voor alle gerechten en voor alle procedures in werking getreden per 1 september 2017 (bijv. art. 19 lid 2 en art. 30p Rv KEI).

7. Dit is nader uitgewerkt zoals is neergelegd in het door de Raad voor de rechtspraak neergelegde Basisplan digitalisering civiel recht en bestuursrecht (reset digitalisering KEI). Te raadplegen via www. rechtspraak.nl/SiteCollectionDocuments/basisplan-reset-digitaliseringciviel-en-bestuur-versie-1.0.pdf. Zie in deze aflevering het artikel van Dineke de Groot over digitaal procederen.

8. Zie Kamerstukken $2018 / 19,35175,3$, p. 2-3. Er is daarom afgezien van internetconsultatie en de Raad van State is om versneld advies gevraagd. 
Wetgeving van 2016, die per 1 maart 2017 zijn ingevoerd, voor zover van toepassing (art. 406 en art. $407 \mathrm{Rv}$ en de door art. 418a $\mathrm{Rv}$ ingeschakelde bepalingen), echter gelden voor vorderingsprocedures.

Het Wetsvoorstel Spoedwet KEI behelst echter meer dan de intrekking van de verplichting tot digitaal procederen bij de rechtbanken Gelderland en Midden-Nederland. De wetgever grijpt ook de gelegenheid aan om enkele, volgens de wetgever, procesvernieuwende bepalingen uit de Wetgeving van 2016 landelijk in werking te laten treden, die zien op de regiefunctie van de rechter en de verruiming van de mogelijkheden tijdens de mondelinge behandeling. Deze procesvernieuwende bepalingen worden neergelegd in de huidige art. 87-90 Rv. Aan de invoering van deze bepalingen, die het democratische proces hebben doorlopen en tot wet zijn verheven, staan de problemen betreffende het digitaal procederen niet in de weg. Deze bijdrage focust zich op deze procesvernieuwingen. De wetgever heeft de betreffende bepalingen willen incorporeren, zodat rechters, partijen en hun advocaten kunnen profiteren van de versterkte regiefunctie van de rechter en de uitgebreidere mogelijkheden voor de mondelinge behandeling, waarmee bij de pilotgerechten positieve ervaringen zijn opgedaan. ${ }^{9}$ In deze bijdrage staat de vraag centraal of en in hoeverre, zoals de wetgever stelt, van procesvernieuwingen kan worden gesproken. Ter beantwoording van deze vraag bespreek ik de bepalingen betreffende de mondelinge behandeling uit het Wetsvoorstel Spoedwet KEI afgezet tegen de huidige werkwijze rondom de mondelinge behandeling alsook de Wetgeving van 2016 (zie par. 3 t/m 8). Alvorens ik inga op de belangrijkste wijzigingen, sta ik eerst stil bij de achtergrond van de wijzigingen betreffende de mondelinge behandeling in het Wetsvoorstel Spoedwet KEI (par. 2).

\section{Achtergrond voorgestelde wijzigingen betreffende de mondelinge behandeling in het Wetsvoorstel Spoedwet KEI}

Het Wetsvoorstel Spoedwet KEI is een vervolg op de Wetgeving van 2016. ${ }^{10}$ Met de Wetgeving van 2016 zijn vijf wezenlijke veranderingen beoogd. Allereerst wordt met deze wetgeving het onderscheid tussen de dagvaarding en het verzoekschrift afgeschaft en beginnen alle civiele procedures met een meer geüniformeerde procesinleiding, waardoor de verschillen tussen procedures over vorderingen en verzoeken zouden verminderen. Ten tweede wordt in de Wetgeving van 2016 de verplichting tot het betekenen bij exploot van de procesinleiding in de vorderingsprocedure afgeschaft. Ten derde worden met de Wetgeving van 2016 meer wettelijke termijnen ingevoerd voor het verrichten van proceshandelingen. De vierde verandering houdt in dat de rechter door een versterkte regiefunctie meer sturing kan geven aan het verloop van de procedure, onder meer door het vroegtijdig overleggen met partijen. De laatste wezenlijke verandering ziet op de digitalisering van de procedure. Het starten van een civiele procedure

9. Zie Kamerstukken II 2018/19, 35175, 3, p. 2-3.

10. Zie Stb. 2016, 288-294. en het verdere verloop van deze procedure dienen in beginsel digitaal plaats te vinden. ${ }^{11}$

Met het Wetsvoorstel Spoedwet KEI wordt de vierde beoogde verandering grotendeels verwezenlijkt. Met de Wetgeving van 2016 worden de civiele rechter meer mogelijkheden geboden om regie te voeren op het verloop van de procedure. Dit uitgangspunt is neergelegd in art. 19 lid $2 \mathrm{Rv}$, waarin is bepaald dat de rechter ambtshalve of op verlangen van een van de partijen alle beslissingen neemt die nodig zijn voor een goed verloop van de procedure. Met deze bepaling heeft de wetgever willen benadrukken dat de rechter medeverantwoordelijk is voor een voorspoedig verloop van de procedure. ${ }^{12}$ Deze bepaling is reeds op 1 september 2017 voor alle gerechten in werking getreden voor alle procedures. ${ }^{13} \mathrm{Wat}$ betreft de regiefunctie dient te worden gedacht aan het bewaken van de voortgang van de procedure, het bevelen van (één of meer der) partijen stukken over te leggen indien dit voor de oordeelsvorming noodzakelijk is, en regie rondom de mondelinge behandeling. Voordat een rechter een regiebeslissing neemt, dienen partijen te worden gehoord (vergelijk art. 19 lid $1 \mathrm{Rv}$ ). De wetgever heeft ervoor gekozen dat instemming van partijen niet nodig is, omdat de wetgever de kans dat partijen hierover overeenstemming zullen bereiken gering achtte. In het geval partijen wel overeenstemming bereiken, zal de rechter hier volgens de wetgever doorgaans gehoor aan geven. ${ }^{14}$

De wetgever makt met het Wetsvoorstel Spoedwet KEI mogelijk dat de bepalingen betreffende de regiefunctie van de rechter en de mondelinge behandeling uit de Wetgeving van 2016 (art. 30k-30n Rv KEI) beschikbaar komen voor de rechtspraktijk. ${ }^{15}$ Deze artikelen worden in het Wetsvoorstel Spoedwet KEI, op enkele terminologische aanpassingen na, zo letterlijk mogelijk overgenomen in art. 87-90 Rv Spoedwet. Deze bepalingen zijn opgenomen in de tweede titel van Boek I $\mathrm{Rv}$ over de dagvaardingsprocedure, maar gelden overeenkomstig het met het Wetsvoorstel Spoedwet KEI gewijzigde art. 279 slot Rv Spoedwet ook voor verzoekschriftprocedures ${ }^{16}$ en zijn als gevolg van de schakelbepalingen van art. $353 \mathrm{Rv}$ en art. 362 jo. art. $284 \mathrm{Rv}$ Spoedwet eveneens van overeenkomstige toepassing in hoger beroep. ${ }^{17}$ Deze bepalingen gelden echter niet voor cassatie. Via de schakelbepaling van art. 408 lid $2 \mathrm{Rv}$ KEI blijven in cassatie art. 30j en 30k Rv KEI uit de Wetgeving van 2016 gelden die per 1 maart 2017 reeds in werking zijn getreden. ${ }^{18}$ Het Wetsvoorstel Spoedwet KEI trekt deze bepalingen immers niet in voor de vorderingsprocedure bij de Hoge Raad en wijzigt evenmin art. 408 lid 2 Rv KEI. Het

11. Zie Kamerstukken II 2014/15, 34059, 3, p. 5-8.

12. Zie H.M.M. Steenberghe \& J.D.A. den Tonkelaar (red.), Commentaar \& Context KEI. Het gewijzigde Wetboek van Burgerlijke Rechtsvordering becommentarieerd vanuit de parlementaire geschiedenis van de KEI-wetgeving, Den Haag: Boom Juridisch 2017, p. 23.

13. Zie Stb. 2017, 174

14. Zie Kamerstukken II 2014/15, 34059, 3, p. 58.

15. Zie wet van 13 juni 2016, Stb. 2016, 288.

16. Zie Kamerstukken II 2018/19, 35175, 3, p. 10.

17. Zie Kamerstukken II 2018/19, 35175, 3, p. 10.

18. Zie Stb. 2017, 16. 
Wetsvoorstel Spoedwet KEI laat, naast de wijzigingen betreffende digitalisering (art. 30c-30f Rv KEI), de bepalingen betreffende de indiening van een zaak bij een gerecht door middel van een procesinleiding en oproepingsbericht (art. 30a en 111-113 Rv KEI), de gezamenlijke behandeling van verzoeken en vorderingen (art. 30b Rv KEI), de algemene voorschriften betreffende de vorderings- en verzoekprocedure (art. 30g-30j Rv KEI) en de invoering en aanscherping van de wettelijke termen buiten beschouwing. ${ }^{19}$ Het huidige art. 90 $\mathrm{Rv}$, waaruit volgt dat de zaak na de comparitie na antwoord weer op de rol komt voor de bepaling van de nadere proceshandeling, is in het Wetsvoorstel Spoedwet KEI neergelegd in art. $91 \mathrm{Rv}$ Spoedwet.

Sinds de wijziging van het Wetboek van Burgerlijke Rechtsvordering in 2002 en de opkomst van de comparitie na antwoord is de regiefunctie van de rechter rondom de mondelinge behandeling reeds versterkt. ${ }^{20}$ Met de invoering van art. 87-90 Rv Spoedwet is dan ook deels sprake van de codificatie van een in de praktijk ontwikkelde werkwijze. ${ }^{21}$ De invoering van art. 87-90 Rv Spoedwet is van belang om te bewerkstelligen dat de in de praktijk gegroeide werkwijze als norm wordt uitgedragen en in de praktijk van alledag wordt toegepast door alle rechters. Hiervoor is het van belang dat rechters zo veel mogelijk overeenkomstig deze bepalingen handelen, ondanks dat de bepalingen als een bevoegdheid zijn geformuleerd. De wetgever heeft de bepalingen slechts als een bevoegdheid van de rechter geformuleerd, zodat de rechter ruimte behoudt om in een voorkomend geval, met het oog op de behoeften van partijen, meer maatwerk te bieden. ${ }^{22}$

\section{Recht op een mondelinge behandeling}

Op grond van art. 6 EVRM hebben partijen recht op een oral hearing. Het recht op een oral hearing maakt enerzijds deel uit van het in art. 6 EVRM neergelegde beginsel van een openbare behandeling van de zaak en anderzijds van het recht op een eerlijke behandeling van de zaak door een onafhankelijke en onpartijdige rechter, dat onder meer het recht op een rechterlijk gehoor omvat. ${ }^{23}$

In het huidige Wetboek van Burgerlijke Rechtsvordering is dit recht gewaarborgd door art. $131 \mathrm{Rv}$, waarin is bepaald dat na de conclusie van antwoord standaard een comparitie wordt gelast, en art. $134 \mathrm{Rv}$, waarin het pleidooi is neergelegd.

19. Zie Kamerstukken II $2018 / 19,35175$, 3, p. 4.

20. Zie H.F.M. Hofhuis, 'Vernieuwing van het civiele proces', Trema 2015, afl. 1, p. 12; C.J.M. Klaassen, 'Kroniek civiele rechtspleging', NJB 2015, p. 1029; A.I.M. van Mierlo \& P.J.J. Vonk, 'Vereenvoudiging en digitalisering van het procesrecht; procederen in nieuwe jas na KEI', WPNR 2015/7065, par. 6; J.D.A. den Tonkelaar, 'De regisserende zaaksrechter: de regierol van de rechter volgens KEI', TCR 2015, afl. 4, p. 109.

21. Zie ook A. Hammerstein tijdens het plenair debat van 19 mei 2015 van het wetsvoorstel Wijziging van het Wetboek van Burgerlijke Rechtsvordering en de Algemene wet bestuursrecht in verband met vereenvoudiging en digitalisering van het procesrecht (34059) (Handelingen II 2014/15, 84-13-12). Zie ook Hofhuis 2015, p. 12-13.

22. Kamerstukken II 2014/15, 34138, 3, p. 27.

23. Zie G. de Groot, 'Rechtsregels met betrekking tot de mondelinge behandeling', in: G. de Groot \& H. Steenberghe (red.), De mondelinge behandeling in civiele zaken, Den Haag: Boom Juridisch 2019, p. 139-182 (p. 146).
Het recht op een oral hearing is eveneens in de Wetgeving van 2016 en het Wetsvoorstel Spoedwet KEI gewaarborgd. Zoals hierna zal blijken, heeft dit recht op een iets andere wijze vorm gekregen in het Wetsvoorstel Spoedwet KEI dan in de Wetgeving van 2016. Zowel in de Wetgeving van 2016 als in het Wetsvoorstel Spoedwet KEI is het uitgangspunt dat, na indiening van het procesinleidende stuk en het antwoord daarop, een mondelinge behandeling plaatsvindt. In de Wetgeving van 2016 is dit neergelegd in art. 30j Rv KEI en in het Wetsvoorstel Spoedwet KEI is dit neergelegd in art. $131 \mathrm{Rv}$ Spoedwet. In de Wetgeving van 2016 is met de invoering van art. 30j Rv KEI art. $131 \mathrm{Rv}$ komen te vervallen. In het Wetsvoorstel Spoedwet KEI is art. $131 \mathrm{Rv}$ echter behouden, zij het met enkele terminologische wijzigingen, en treedt het voor de rechtbanken Gelderland en Midden-Nederland opnieuw in werking. Op dit punt vindt geen wijziging plaats ten opzichte van de huidige procedure, waar reeds het uitgangspunt is dat na de conclusie van antwoord door de rechter een comparitie wordt bevolen. ${ }^{24}$ Art. $134 \mathrm{Rv}$ betreffende het pleidooi komt in het Wetsvoorstel Spoedwet KEI, in lijn met de Wetgeving van 2016, echter wel te vervallen. In de praktijk komt het pleidooi in eerste aanleg echter zelden voor als gevolg van de uitzondering van art. 134 lid $1 \mathrm{Rv}$, dat partijen al bij de comparitie hun standpunt mondeling uiteen hebben kunnen zetten. De mondelinge behandeling als bedoeld in art. 131 jo. art. $87 \mathrm{Rv}$ Spoedwet heeft, evenals de mondelinge behandeling in het eerdere art. 30k Rv KEI, wel deels een pleitkarakter. In art. 87 lid $1 \mathrm{Rv}$ Spoedwet is, overeenkomstig art. 30k lid 2 Rv KEI, bepaald dat de rechter partijen tijdens de mondelinge behandeling in de gelegenheid stelt om hun stellingen toe te lichten. Uit het voorgaande volgt dat het recht op een oral hearing in het Wetsvoorstel Spoedwet KEI op een wijze wordt gewaarborgd die overeenstemt met de huidige praktijk.

Het recht op een mondelinge behandeling is, volgens de vaste rechtspraak van het EHRM, niet absoluut. Dit recht kan ook in bepaalde gevallen achterwege blijven. In overeenstemming met de rechtspraak van het EHRM zijn in de Wetgeving van 2016 in art. 30j lid 6 Rv KEI twee typen gevallen opgenomen waarin de mondelinge behandeling achterwege kan blijven. ${ }^{25}$ Volgens deze bepaling kan een mondelinge behandeling allereerst achterwege blijven wanneer dit met instemming of op verlangen van partijen geschiedt. Ten tweede kan de rechter in kantonzaken bepalen dat de mondelinge behandeling achterwege blijft indien geen van partijen, nadat zij zijn gewezen op hun recht te worden gehoord, binnen een door hem gestelde redelijke termijn heeft verklaard dat zij gebruik wil maken van dit recht. Art. 30j lid 6 Rv KEI wordt niet ingevoerd met het Wetsvoorstel Spoedwet KEI. Ook onder de Spoedwet KEI is het echter mogelijk dat de rechter een mondelinge behandeling achterwege laat. ${ }^{26}$ De wetgever heeft in het Wetsvoorstel Spoedwet KEI aan art. 87 Rv Spoedwet een vangnetbepaling toegevoegd om duidelijk te maken dat in

24. Zie H.J. Snijders, C.J.M. Klaassen \& G.J. Meijer, Nederlands burgerlijk procesrecht, Deventer: Kluwer 2011, nr. 146.

25. Zie hierover uitgebreid De Groot 2019, p. 147-148

26. Zie Kamerstukken II 2018/19, 35175, 3, p. 9. 
gevallen waarin geen mondelinge behandeling heeft plaatsgevonden partijen hier wel aanspraak op kunnen maken. Art. 87 lid $8 \mathrm{Rv}$ Spoedwet bepaalt dat in het geval geen mondelinge behandeling heeft plaatsgevonden, de rechter voordat hij over de zaak beslist aan partijen desverlangd de gelegenheid biedt om hun standpunt mondeling uiteen te zetten. Hiermee heeft de wetgever het recht op een mondelinge behandeling wettelijk verankerd. ${ }^{27}$ Art. 87 lid 8 Rv Spoedwet verschilt van art. 30j lid $6 \mathrm{Rv}$ KEI in de zin dat art. 30j lid 6 Rv KEI uitdrukkelijke instemming van partijen vereist om de mondelinge behandeling achterwege te laten. Voor kantonzaken is in art. 30j Rv KEI opgenomen dat partijen op dit recht dienen te worden gewezen en een termijn dient te worden gegeven waarin partijen kenbaar dienen te maken dat zij een mondelinge behandeling wensen. Maken partijen een dergelijke wens niet kenbaar, dan wordt aangenomen dat partijen instemmen met het achterwege laten van een mondelinge behandeling. ${ }^{28}$ Dit betekent dat de griffie in zaken waar geen mondelinge behandeling is bevolen, alvorens een datum voor het vonnis of de beschikking wordt bepaald, eerst een brief aan partijen dient te versturen waarin partijen op dit recht worden gewezen, en in geval van kanton een redelijke termijn wordt gegeven waarin een partij kenbaar dient te maken dat zij een mondelinge behandeling wenst. Hier is de wetgever echter in het Wetsvoorstel Spoedwet KEI vanaf gestapt en kan de rechter zonder partijen hierover eerst te informeren afzien van een mondelinge behandeling. Wel dient een verzoek tot een mondelinge behandeling te worden gehonoreerd wanneer deze niet heeft plaatsgevonden. Art. 87 lid 5 Rv Spoedwet stemt overeen met de werkwijze van de (meeste) gerechten in kantonzaken. Mijns inziens zou het wenselijk zijn geweest als de wetgever op dit punt ook art. 30j lid $6 \mathrm{Rv}$ KEI had overgenomen, ondanks dat dit leidt tot een verzwaring van de administratieve last van de gerechten. Op deze wijze wordt immers voor partijen werkelijk het recht op een oral hearing gewaarborgd, doordat partijen bewust afstand doen van dit recht.

\section{Dagbepaling en oproeping voor de mondelinge behandeling}

In de Wetgeving van 2016 is in art. 30j lid $1 \mathrm{Rv}$ KEI bepaald dat de rechter, in geval van een vorderingsprocedure, zo spoedig mogelijk nadat de verweerder in de procedure is verschenen, en in geval van een verzoekprocedure na ontvangst van de procesinleiding, de dag en het uur waarop de mondelinge behandeling plaatsvindt, dient te bepalen. Dit moet bevorderen dat partijen en de rechter in een zo vroeg mogelijk stadium contact hebben. ${ }^{29}$ In de Wetgeving van 2016 zijn art. 131 en art. $279 \mathrm{Rv}$ betreffende de dagbepaling van een mondelinge behandeling in een dagvaardingsprocedure respectievelijk een verzoekschriftprocedure vervallen. Art. 30j Rv KEI wordt echter met het Wetvoorstel Spoedwet KEI niet landelijk ingevoerd. De huidige art. 131 en 279 Rv blijven gehandhaafd, met slechts enkele terminologische wijzigingen. Dit betekent dat

27. Zie Kamerstukken II 2018/19, 35175, 3, p. 9.

28. Zie Steenberghe \& Den Tonkelaar 2017, p. 87

29. Zie Kamerstukken II 2014/15, 34059, 3, p. 27. in de dagvaardingsprocedure de rechter, nadat de gedaagde voor antwoord heeft geconcludeerd, bij tussenvonnis of rolbeschikking een datum voor de mondelinge behandeling bepaalt (art. $131 \mathrm{Rv).} \mathrm{In} \mathrm{de} \mathrm{verzoekschriftprocedure} \mathrm{bepaalt} \mathrm{de} \mathrm{rechter}$ onverwijld dag en uur waarop de mondelinge behandeling plaatsvindt (art. 279 lid $1 \mathrm{Rv}$ ). De oproeping geschiedt door de griffier bij gewone brief (art. 271 lid $1 \mathrm{Rv}$ ). Het Wetsvoorstel Spoedwet KEI brengt dus geen wijziging op het punt van de oproeping van partijen en het moment waarop de mondelinge behandeling plaatsvindt.

\section{Invulling van de mondelinge behandeling}

\subsection{Doelen van de mondelinge behandeling}

De mondelinge behandeling is bedoeld als een centraal onderdeel van de civiele procedure waarmee een goed en efficiënt verloop van de procedure wordt gediend. ${ }^{30}$ In art. 87 lid $2 \mathrm{Rv}$ Spoedwet zijn de doelen van de mondelinge behandeling neergelegd. Deze bepaling stemt overeen met art. 30k lid 1 Rv KEI. Naast dat partijen tijdens de mondelinge behandeling de mogelijkheid krijgen hun stellingen toe te lichten, kan de rechter ook partijen verzoeken om inlichtingen te geven, partijen de gelegenheid geven hun stellingen nader te onderbouwen, een schikking beproeven, met partijen overleggen over het vervolg van de procedure en/of aanwijzingen geven of proceshandelingen bevelen die hij geraden acht. De comparitie na antwoord heeft volgens de wet tot doel het beproeven van een schikking (art. $87 \mathrm{Rv}$ ) en het verkrijgen van inlichtingen (art. $88 \mathrm{Rv}$ ), maar wordt in de praktijk ook gebruikt om het verloop van de procedure te bespreken. ${ }^{31}$ Met de Wetgeving van 2016 en het Wetsvoorstel Spoedwet KEI wordt dit laatste doel ook wettelijk geregeld.

Zoals gezegd vervalt met het Wetsvoorstel Spoedwet KEI art. $134 \mathrm{Rv}$ en daarmee het wettelijke recht op pleidooi. Ook onder de Wetgeving van 2016 is art. $134 \mathrm{Rv}$ vervallen. In het Wetsvoorstel Spoedwet KEI komt hiervoor de mogelijkheid van partijen om hun stellingen bij de mondelinge behandeling toe te lichten in de plaats (art. 87 lid $1 \mathrm{Rv}$ Spoedwet). Dit is geen discretionaire bevoegdheid van de rechter. Art. 87 lid 1 $\mathrm{Rv}$ Spoedwet is, evenals art. 30k lid $2 \mathrm{Rv}$ KEI, imperatief geformuleerd. Algemeen wordt aangenomen dat partijen een bepaalde spreektijd krijgen die zij naar eigen inzicht kunnen invullen om hun stellingen toe te lichten. ${ }^{32}$ Hiermee wordt een einde gemaakt aan de huidige discussie of tijdens de comparitie na antwoord wel of niet door partijen een toelichting mag worden gegeven op de zaak, en wordt op dit punt unifor-

30. Zie Kamerstukken II 2014/15, 34059, 3, p. 27 en 70.

31. Zie H.J. Snijders, C.J.M. Klaasen \& G.J. Meijer, Nederlands burgerlijk procesrecht, Deventer: Wolters Kluwer 2018, nr. 145.

32. Zie K. Teuben \& K.J.O. Jansen, 'Het Wetsvoorstel vereenvoudiging en digitalisering procesrecht: kanttekeningen vanuit de procespraktijk', TCR 2015, afl. 2, p. 3-12 (p. 7); C.J.M. Klaasen, 'Het recht op pleidooi, mede in het licht van en zicht van "KEI": een terug- en vooruitblik', $A A$ 2016 , p. $185-190$ (p. 189); M. Ashmann, 'Van comparitie naar mondelinge behandeling. Over de rol van de pleitnota', NJB 2017/1797, par. 4. 
miteit gecreëerd. ${ }^{33}$ In de huidige praktijk gaan, tot ongenoegen van menig advocaat, gerechten verschillend om met de vraag of een partij de mogelijkheid krijgt tijdens de mondelinge behandeling om de zaak toe te lichten, al dan niet aan de hand van spreekaantekeningen. ${ }^{34}$ In het Wetsvoorstel Spoedwet KEI wordt echter, evenals in de Wetgeving van 2016, geen duidelijkheid gegeven over de vraag of de mondelinge toelichting mag plaatsvinden aan de hand van spreekaantekeningen. ${ }^{35}$ Mijns inziens past bij een mondelinge behandeling, waarin partijen de gelegenheid moeten krijgen om hun stellingen toe te lichten, dat zij dit ook mogen doen aan de hand van spreekaantekeningen. ${ }^{36}$ Vanuit oogpunt van efficiëntie dient mijns inziens de mondelinge toelichting aan het begin van de mondelinge behandeling plaats te vinden, zodat eventuele vraagpunten bij de rechter kunnen worden weggenomen. Daarnaast wordt voorkomen dat voor partijen belangrijke punten onvoldoende aandacht krijgen doordat ze nog aan het einde van de zitting in de dan nog resterende zittingstijd slechts beperkt naar voren kunnen worden gebracht. Na deze mondelinge toelichting kan vervolgens de interactie tussen partijen en de rechter plaatsvinden, die de Wetgeving van 2016 alsook het Wetsvoorstel Spoedwet KEI voor ogen staat en ook noodzakelijk is met het oog op de waarheidsvinding. Het verdient aanbeveling voor een efficiënt verloop van de mondelinge behandeling dat op dit punt duidelijkheid wordt geboden in de uitnodiging voor de mondelinge behandeling, zoals ook is neergelegd in art. 4.1.4 van het Landelijk procesreglement civiele zaken rechtbanken en gerechtshoven KEI (hierna: Procesreglement KEI). Bij de rechtbanken Gelderland en Midden-Nederland werden spreekaantekeningen (van twee A4'tjes) standaard toegestaan, waarbij de spreektijd in de meeste gevallen werd beperkt tot vijf minuten. ${ }^{37}$ In een omvangrijke zaak zal een spreektijd van vijf minuten echter veelal niet voldoende zijn. Mijns inziens dient de spreektijd aan de hand van de schriftelijke stukkenwisseling bij voorkeur in overleg met partijen en de advocaten te worden vastgesteld. Op deze wijze wordt maatwerk geboden, zoals ook is beoogd met de Wetgeving van 2016 en de Spoedwet KEI. Partijen zouden zich hierover kunnen uitlaten tegelijkertijd met de uitlating over de hierna te bespreken zittingsagenda. Hierbij kan partijen wel enige richting worden gegeven door in een procesreglement een standaard spreektijd op te nemen, die ook wordt gehanteerd wanneer partijen zich niet uitlaten over de

33. Zie Teuben \& Jansen 2015, p. 7; Klaassen 2016, p. 189; Ashmann 2017, par. 4; Steenberghe \& Den Tonkelaar 2017, p. 102.

34. Zie R.B. Gerretsen, 'Comparitienotities', in: De mondelinge behandeling, negen jaar met het nieuwe burgerlijk procesrecht, Den Haag: Boom Juridisch 2011, p. 43-52 (p. 47-49); Klaassen 2016, p. 189.

35. Zie hierover uitgebreid Ashmann 2017, par. 6; C.J-A. Seinen, 'Hart, handen \& voeten: de mondelinge behandeling en de pleitnota na KEI', TCR 2017, afl. 2, p. 39-47 (p. 40-42).

36. Zie ook C.J.M. Klaassen, 'Advocaat "let op uw saeck"', NJB 2017/617, par. 5.1; Anders Ashmann 2017, par. 6.

37. Zie ook H. ten Haaft, 'De mondelinge behandeling vanuit het perspectief van de advocaat', in: G. de Groot \& H. Steenberghe (red.), De mondelinge behandeling in civiele zaken, Den Haag: Boom Juridisch 2019, p. 473-505 (p. 491). spreektijd, zoals dat nu ook het geval is wanneer partijen geen verlenging van spreektijd hebben aangevraagd.

Uit art. 87 lid 4 Rv Spoedwet (art. 30k lid 2 Rv KEI) volgt ook dat de griffier voor zover mogelijk partijen tevoren bericht over het doel van de zitting, zodat partijen en hun rechtsbijstandverleners weten wat ze kunnen verwachten en zich zo goed mogelijk op de zitting kunnen voorbereiden. ${ }^{38}$ Hiermee worden rechters verder aangespoord om te werken met een zittingsagenda, waarmee door sommige rechters in de praktijk al wordt gewerkt. ${ }^{39}$ In het Procesreglement KEI is de zittingsagenda in art. 4.1 .5 neergelegd. Uit deze bepaling volgt dat aan partijen het doel van de mondelinge behandeling wordt meegedeeld alsmede dat nadere aanwijzingen kunnen worden gegeven over de vraagpunten of onderwerpen die de rechter wil bespreken. Zowel in de wet als in het Procesreglement KEI is de zittingsagenda niet verplicht voorgeschreven. Ten Haaft heeft terecht opgemerkt dat met de zittingsagenda ook echt invulling kan worden gegeven aan de versterkte regierol van de rechter. ${ }^{40} \mathrm{Om}$ art. 87 lid $4 \mathrm{Rv}$ Spoedwet werkelijk een procesvernieuwing te laten zijn, zouden rechters met de door de advocatuur toegejuichte zittingsagenda moeten gaan werken, ondanks dat deze zittingsagenda niet dwingend is voorgeschreven. Slechts op deze manier kan de zittingsagenda in de toekomst ook standaardpraktijk worden. De zittingsagenda draagt bij aan een efficiënt verloop van de mondelinge behandeling, doordat advocaten weten wat tijdens de mondelinge behandeling wordt besproken, waardoor zij zich hierop beter kunnen voorbereiden. ${ }^{41}$ Deze zittingsagenda dient, zoals reeds in de literatuur is bepleit, ${ }^{42}$ mijns inziens zo veel mogelijk in overleg met partijen en hun advocaten te worden vastgesteld. De partijen en hun advocaten zullen, op basis van de schriftelijke stukkenwisseling en de al aanwezige kennis van het dossier, wellicht nog beter dan de rechter in staat zijn om te bepalen welke onderwerpen nog een nadere toelichting vereisen, omdat zij betreffende die onderwerpen van mening verschillen. Het verdient aanbeveling dat partijen zich ook op dit punt kunnen uitlaten alvorens de mondelinge behandeling wordt bepaald.

In het kader van de invulling van de mondelinge behandeling is eveneens art. $88 \mathrm{Rv}$ Spoedwet van belang, waarin de inhoud van art. 88 lid 2 en lid $4 \mathrm{Rv}$, zoals dat nu geldt voor de niet-KEI-procedures, terugkomt. Art. 88 lid 1 Rv Spoedwet regelt de gang van zaken indien het doel van de mondelinge behandeling het verkrijgen van inlichtingen is. Art. 88 lid $2 \mathrm{Rv}$ Spoedwet regelt de waarde van een partijverklaring en de gevolgtrekking die de rechter kan verbinden aan afgelegde verklaringen, het niet-verschijnen op de mondelinge behandeling of het weigeren om te antwoorden of het proces-verbaal te ondertekenen.

38. Zie Kamerstukken II 2014/15, 34059, 3, p. 72.

39. Zie De Groot 2019, p. 164.

40. Zie Ten Haaft 2019, p. 489-490.

41. Zie Steenberghe \& Den Tonkelaar 2017, p. 104.

42. H.H.M. Steenberghe, 'Regie als model voor samenwerking', Trema 2017 , afl. 6, par. 4.3; Seinen 2017, p. 41-42; De Groot 2019, p. 165. 


\subsection{Het horen van getuigen en deskundigen op de mondelinge behandeling}

In navolging van art. 30k lid 2 Rv KEI wordt in art. 87 lid 3 Rv Spoedwet bepaald dat, met voorafgaande toestemming van de rechter, tijdens de mondelinge behandeling getuigen en partijdeskundigen kunnen worden gehoord. Op dit verhoor van de getuigen en deskundigen tijdens de mondelinge behandeling zijn de voorschriften van het wettelijke bewijsrecht van toepassing. Dit betekent bijvoorbeeld dat oproeping overeenkomstig art. $170 \mathrm{Rv}$ dient plaats te vinden. Uit de verwijzing naar art. 284 lid $1 \mathrm{Rv}$ volgt dat deze bepaling ook van toepassing is in verzoekschriftprocedures, tenzij de aard van de procedure zich hiertegen verzet. Onder het huidige Wetboek van Burgerlijke Rechtsvordering, zoals dat thans geldt voor niet-KEI-zaken, is het reeds mogelijk om getuigen ter zitting te horen door op de betreffende zitting een mondeling tussenvonnis te wijzen en dit in het proces-verbaal op te nemen (art. $232 \mathrm{Rv}$ ). Art. 87 lid $3 \mathrm{Rv}$ Spoedwet geeft hieraan een vervolg, tegen de achtergrond dat partijen in de huidige praktijk ter comparitie nogal eens worden vergezeld door personen die geen partij zijn, maar wel bij de zaak betrokken zijn en als informant inlichtingen kunnen geven die relevant zijn voor de beslissing door de rechter in de zaak. ${ }^{43}$ Teneinde te verzekeren dat de verstrekking van informatie tijdens de mondelinge behandeling met voldoende waarborgen is omgeven voor de totstandkoming van bewijsmateriaal en om de rechter in staat te stellen de informatie te betrekken bij de beslissing na de mondelinge behandeling, voorziet art. 87 lid 3 Rv Spoedwet (in navolging van art. $30 \mathrm{k}$ lid $2 \mathrm{Rv} \mathrm{KEI}$ ) in de mogelijkheid dergelijke personen naargelang de aard van hun informatie als getuige of deskundige aan de zijde van een partij te horen. Een voorafgaande bewijsopdracht of bevel tot een deskundigenbericht is niet nodig voor het meebrengen van getuigen en/of deskundigen. Wel dient de rechter toestemming te hebben verleend.

Voordeel van deze mogelijkheid is dat geen aparte zittingen hoeven te worden gepland waar getuigen en deskundigen worden gehoord. In de literatuur zijn er echter ook verschillende risico's gesignaleerd die aan het horen van getuigen en deskundigen tijdens de mondelinge behandeling zijn verbonden. Zo wordt gevreesd dat, omdat een probandum ontbreekt, partijen een veelheid aan getuigen zullen meenemen. ${ }^{44}$ Ook kan de schikkingsbereidheid van partijen afnemen omdat het geschil wordt gejuridiseerd doordat partijen in een vroeg stadium van de procedure verschijnen met mogelijke getuigen en deskundigen. ${ }^{45}$ Verder kan achteraf blijken dat bewijslevering ten aanzien van het thema waarover getuigen en/of deskundigen zijn gehoord helemaal niet nodig was. ${ }^{46}$ Voorts kan het

43. Zie Kamerstukken II 2014/15, 34059, 3, p. 71. Zie ook De Groot 2019, p. 166-167.

44. Zie Hofhuis 2015, p. 13; Teuben \& Jansen 2015, p. 7; Van Mierlo \& Vonk 2015, p. 514-515.

45. Zie Teuben \& Jansen 2015, p. 7; Hofhuis 2015, p. 13.

46. Zie Hofhuis 2015, p. 13; Teuben \& Jansen 2015, p. 7; Van Mierlo \& Vonk 2015, p. 514-515. horen van getuigen en deskundigen ter zitting tot een verstoring van de gelijkheid van partijen leiden. ${ }^{47}$

Een deel van deze risico's kan worden geneutraliseerd doordat de rechter gebruik maakt van zijn regiebevoegdheden. Het horen van getuigen en deskundigen op de mondelinge behandeling vereist immers voorafgaande toestemming van de rechter, zo volgt uit art. 87 lid 3 Rv Spoedwet. Hierbij dient de rechter voor ogen te houden dat de wetgever deze mogelijkheid vooral heeft bedoeld om in zaken met een betrekkelijk eenvoudige feitelijke grondslag tijdens de mondelinge behandeling het bewijs op tafel te leggen, zodat daarna de zaak kan worden afgedaan. ${ }^{48}$ Zodra het om een ingewikkelde procedure gaat waar tussen partijen meer discussie bestaat over de feiten en bewijslevering, zal de rechter geen toestemming voor het horen van getuigen dienen te verlenen. ${ }^{49}$ Partijen kunnen de rechter behulpzaam zijn door kenbaar te maken of behoefte bestaat aan het horen van getuigen en/of deskundigen op de mondelinge behandeling, hoeveel getuigen en/of deskundigen men wil horen, en waarover de voorgestelde getuigen en/of deskundigen kunnen verklaren. Op basis hiervan kan de rechter vervolgens bepalen of de zaak geschikt is om getuigen en/of deskundigen op de mondelinge behandeling te horen. Zoals reeds door mij is bepleit in paragraaf 5.1 in het kader van de zittingsagenda, verdient het mijns inziens dan ook aanbeveling dat partijen, voordat de mondelinge behandeling wordt bepaald, de gelegenheid kriigen zich uit te laten over de invulling van de mondelinge behandeling, waarbij naast een suggestie voor de spreektijd en de te bepreken onderwerpen ook gemotiveerd kan worden verzocht om getuigen en/of deskundigen te horen. Ondanks het feit dat de rechter voorafgaand aan de mondelinge behandeling een weloverwogen beslissing heeft genomen over het horen van getuigen en/of deskundigen, kan het nog steeds voorkomen dat het horen van de getuigen en/of deskundigen ongelijkheid tussen partijen tot gevolg heeft. Het beginsel van hoor en wederhoor brengt dan mee dat als de rechter een partij toestaat om getuigen mee te nemen naar de zitting, een soortgelijk verzoek van de wederpartij ook gehonoreerd zal moeten worden. Van de wederpartij mag en kan niet worden verwacht dat zij alle potentiële getuigen en/of deskundigen meebrengt naar de mondelinge behandeling. In sommige gevallen zal door de rechter toch een tweede zitting moeten worden gehouden om de getuigen en/of deskundigen van de wederpartij te horen..$^{50}$

\subsection{Procesvertegenwoordiging}

De regels inzake procesvertegenwoordiging blijven in het Wetsvoorstel Spoedwet KEI gelijk (art. 87 lid 5 Rv Spoedwet). In aansluiting op de bestaande regels van art. 79-81 en art. 280 Rv bepaalt art. 87 lid 5 Rv Spoedwet dat partijen in kantonzaken in persoon of bij gemachtigde verschijnen en in zaken waarin zij niet in persoon mogen verschijnen bij advocaat.

47. Zie Hofhuis 2015, p. 13.

48. Zie Handelingen II 2014/15, 84-12-13.

49. Zie ook Steenberghe \& Den Tonkelaar 2017, p. 104

50. Zie Teuben \& Jansen 2015, p. 8; Steenberghe \& Den Tonkelaar 2017, p. 104-105. 
Verder kan de rechter bevelen dat een partij in persoon verschijnt. Art. 87 lid 5 Rv Spoedwet geldt niet voor alle verzoekschriftprocedures. In verzoekschriftprocedures waar geen verplichte procesvertegenwoordiging geldt voor de mondelinge behandeling (art. 279 lid $3 \mathrm{Rv}$ ) verzet de aard van de verzoekschriftprocedure zich tegen toepassing van art. 87 lid $5 \mathrm{Rv}$ Spoedwet (art. 279 lid 6 Rv Spoedwet). De memorie van toelichting zwijgt of art. 87 lid $5 \mathrm{Rv}$ Spoedwet zich ertegen verzet dat partijen tijdens de mondelinge behandeling zelf een mondelinge toelichting geven, zoals dat is neergelegd in art. 134 lid $3 \mathrm{Rv}$, welke bepaling met het Wetsvoorstel Spoedwet KEI komt te vervallen. Mijns inziens blijft deze mogelijkheid bestaan, maar blijft eveneens de verplichting bestaan zich te laten bijstaan door een advocaat.

\section{Indienen van stukken voorafgaand aan de mondelinge behandeling}

Art. 87 lid $6 \mathrm{Rv}$ Spoedwet regelt, op dezelfde wijze als in art. $30 \mathrm{k}$ lid $5 \mathrm{Rv}$ KEI, het moment waarop stukken dienen te worden ingediend voor de mondelinge behandeling en de sanctie bij te late indiening. Art. 87 lid $6 \mathrm{Rv}$ Spoedwet is een codificatie van de bestaande praktijk. Art. 87 lid 6 Rv Spoedwet benadrukt allereerst dat stukken zo veel mogelijk tegelijk met het procesinleidende stuk respectievelijk het antwoord dienen te worden overgelegd. Op grond van de reeds overgelegde stukken kan de rechter vervolgens beoordelen of het nog noodzakelijk is om ex art. $22 \mathrm{Rv}$ overlegging van bepaalde stukken voorafgaand aan de mondelinge behandeling te bevelen (art. 87 lid 7 Rv Spoedwet).

Daarnaast is in art. 87 lid $6 \mathrm{Rv}$ Spoedwet bepaald dat uiterlijk tot tien dagen voor de mondelinge behandeling stukken kunnen worden ingediend. Het doel van deze termijn is dat de rechter en partijen voldoende gelegenheid hebben om de stukken, conclusies en akten voor aanvang van de mondelinge behandeling te bestuderen. De sanctie op het te laat indienen van de stukken is dat de rechter de stukken buiten beschouwing laat. Hierop kan de rechter een uitzondering maken ingeval de goede procesorde zich daartegen verzet. De wetgever geeft als voorbeelden een verzoek tot een omgangsregeling en alimentatie in het geval een van de ouders kort voor de mondelinge behandeling is verhuisd of van baan is veranderd. Uit de memorie van toelichting op art. 30k lid 5 Rv KEI blijkt eveneens dat het ook mogelijk is dat een stuk dat twaalf dagen van tevoren - dus tijdig - is ingediend, niettemin in strijd kan zijn met de goede procesorde wanneer het een omvangrijk stuk betreft waarover de indiener al eerder beschikte. ${ }^{51}$ Of stukken die voor de mondelinge behandeling worden ingediend in de procedure worden betrokken, dient dus te worden beoordeeld aan de hand van de eisen van de goede procesorde.

Art. 87 lid 6 Rv Spoedwet is geen procesvernieuwing, maar een codificatie van een in de praktijk ontwikkelde werkwijze die nu in de procesreglementen is neergelegd. De rechter beschikt onder huidig procesrecht op grond van art. $22 \mathrm{Rv}$ reeds over de mogelijkheid om partijen te bevelen bepaalde

51. Zie Kamerstukken II 2014/15, 34059, 3, p. 72. stukken voor de mondelinge behandeling over te leggen. Daarnaast zijn in de verschillende procesreglementen verschillende termijnen neergelegd voor de indiening van producties en bijlagen, die variëren van vijf werkdagen tot twee weken voorafgaand aan de mondelinge behandeling. ${ }^{52}$ De wetgever heeft in art. 87 lid $6 \mathrm{Rv}$ Spoedwet aansluiting gezocht bij het bestuursrecht en daarom gekozen voor een termijn van tien dagen. ${ }^{53}$ Met art. 87 lid 6 Rv Spoedwet wordt eveneens de in de rechtspraak ontwikkelde lijn wettelijk verankerd, waaruit volgt dat de goede procesorde bepalend is voor de vraag of een stuk tijdig is ingediend. Zo oordeelde de Hoge Raad in het arrest Dipasa/Huyton dat het antwoord op de vraag of overlegging van stukken kort voor de mondelinge behandeling is toegestaan, afhankelijk is van de aard en omvang van de stukken en of de wederpartij voldoende gelegenheid heeft gehad om van de stukken kennis te nemen om deugdelijk verweer te kunnen voeren. ${ }^{54}$ Andersom heeft de Hoge Raad eveneens beslist dat overgelegde stukken, ingediend binnen de in het Landelijk procesreglement bepaalde termijn, desondanks buiten beschouwing kunnen blijven wegens strijd met de goede procesorde wanneer het gaat om stukken waarvan de aard en omvang een beletsel vormen om daarvan binnen de beschikbare tijd kennis te nemen en daarop adequaat te reageren. ${ }^{55}$

\section{Schikking}

Art. $89 \mathrm{Rv}$ Spoedwet regelt in navolging van art. 30m Rv KEI de schikking die op de mondelinge behandeling wordt bereikt. Deze bepaling geldt via art. 279 lid 6 Rv Spoedwet ook voor verzoekschriftprocedures. De huidige schikkingscomparitie blijft onder de algemene noemer van de mondelinge behandeling ex art. 87 Rv Spoedwet bestaan. ${ }^{56}$ Art. 89 lid 1 Rv Spoedwet komt grotendeels overeen met art. 87 lid $3 \mathrm{Rv}$ en regelt dat wanneer partijen een schikking overeenkomen hiervan een proces-verbaal wordt opgemaakt dat door de rechter, partijen en hun bijzonder gevolmachtigde wordt ondertekend. Art. 89 lid $1 \mathrm{Rv}$ Spoedwet KEI bepaalt eveneens dat wanneer een schikking tot stand komt de procedure eindigt. In het advies van de Adviescommissie burgerlijk procesrecht en het advies van de Hoge Raad naar aanleiding van de wetsvoorstellen die tot de Wetgeving van 2016 hebben geleid, is de vraag aan de orde gesteld op welke wijze de procedure eindigt nadat een schikking is bereikt, en of heropening van de zaak kan worden verzocht wanneer de schikking niet wordt nagekomen. ${ }^{57}$ In de parlementaire behandeling die heeft geleid tot de Wetgeving van 2016 is hieraan geen aandacht besteed en ook in de

52. Zie art. 2.9 Landelijk procesreglement voor civiele dagvaardingszaken bij de rechtbanken; art. 2.15 Landelijk procesreglement voor civiele dagvaardingszaken bij de gerechtshoven; art. 1.4.4 Procesreglement verzoekschriftprocedures rechtbank handel/voorzieningenrechter; art. 1.1.4.4 Procesreglement verzoekschriftprocedures handels- en insolventiezaken gerechtshoven.

53. Zie Kamerstukken II 2014/15, 34059, 3, p. 72.

54. Zie HR 29 november 2002, ECLI:NL:HR:2002:AF1210, NJ 2004/172, m.nt. H.J. Snijders (Dipasa/Huyton).

55. Zie HR 13 december 2010, ECLI:NL:HR:2010:BO0197, NJ 2010/650.

56. Zie Kamerstukken II 2014/15, 34059, 3, p. 73.

57. Zie Steenberghe \& Den Tonkelaar 2017, p. 109. 
memorie van toelichting op het Wetsvoorstel Spoedwet KEI wordt dit punt niet verduidelijkt. Om er zeker van te zijn dat de procedure is geëindigd, dient in het proces-verbaal van de schikking te worden opgenomen dat de zaak wordt doorgehaald op grond van art. $246 \mathrm{Rv}$ en dat partijen hiermee hebben bedoeld de procedure te beëindigen. ${ }^{58}$ Het zal, evenals onder het huidige recht, mogelijk blijven dat een partij de rechter verzoekt de procedure aan te houden gedurende de termijn van nakoming van verbintenissen, waarbij een moment wordt bepaald waarop partijen zich moeten uitlaten over doorhaling of voortzetting. Dit maakt het mogelijk dat een partij de zaak kan hervatten wanneer een partij de uit de schikking voortvloeiende verplichtingen niet nakomt. ${ }^{59}$

Art. 89 lid 2 Rv Spoedwet (art. 30m lid 2 Rv KEI) ziet op de regiebevoegdheid van de rechter wanneer partijen geen schikking bereiken op de mondelinge behandeling. Blijkens de memorie van toelichting op art. 30m lid 2 Rv KEI kan de mondelinge behandeling worden voortgezet voor het verkrijgen van nadere inlichtingen, kan een nieuwe mondelinge behandeling worden gepland om getuigen te horen, of kan de rechter tot de conclusie komen dat hij reeds over voldoende informatie beschikt. Het is voorts mogelijk dat de zitting wordt afgesloten met de aanhouding voor verder schikkingsoverleg. ${ }^{60}$ Wanneer partijen vervolgens tot een schikking komen, kunnen zij verzoeken de schikking neer te leggen in een proces-verbaal, zoals onder het huidige Wetboek van Burgerlijke Rechtsvordering praktijk is. ${ }^{61}$

\section{Proces-verbaal van de zitting}

In art. $90 \mathrm{Rv}$ Spoedwet is het proces-verbaal geregeld. Dit artikel is vrijwel gelijkluidend aan art. 30n Rv KEI. Art. $90 \mathrm{Rv}$ Spoedwet geeft een algemene regeling voor het opstellen van een proces-verbaal ter zitting, ongeacht de aanleiding van het proces-verbaal. Een dergelijk algemeen voorschrift kent het huidige Wetboek van Burgerlijke Rechtsvordering niet. Het proces-verbaal is per aparte proceshandeling geregeld. Zo regelt art. 87 lid $3 \mathrm{Rv}$ het proces-verbaal in geval van een schikkingscomparitie, art. 88 lid $4 \mathrm{Rv}$ het proces-verbaal van de inlichtingencomparitie en art. 279 lid 4 Rv het proces-verbaal van de mondelinge behandeling in een verzoekschriftprocedure. ${ }^{62}$

Uit art. 90 lid $1 \mathrm{Rv}$ Spoedwet volgt dat de rechter niet in alle gevallen een proces-verbaal hoeft op te maken. De rechter beschikt over een zekere vrijheid. ${ }^{63}$ De rechter makt in twee gevallen echter een proces-verbaal op. Dit is allereerst wanneer een partij daarbij belang heeft. Dit is volgens de wetgever het geval wanneer een partij tijdens de mondelinge behandeling bepaalde erkenningen heeft gedaan of bepaalde vorderingen

58. Zie De Groot 2019, p. 168-169.

59. Zie Steenberghe \& Den Tonkelaar 2017, p. 110-111.

60. Zie Kamerstukken II 2014/15, 34059, 3, p. 73.

61. Zie Kamerstukken II 2014/15, 34059, 3, p. 73. Zie over de constructies die hiervoor kunnen worden gebruikt M.W. Knigge, 'Hoe verkrijg ik een executoriale titel? De deugdelijkheid van twee constructies onderzocht', TCR 2018, afl. 3, p. 79-86.

62. Zie Kamerstukken II $2014 / 15,34059,3$, p. 73-74.

63. Zie Steenberghe \& Den Tonkelaar 2017, p. 116. heeft ingetrokken. ${ }^{64}$ Steenberghe en Den Tonkelaar nemen aan dat de toets in dit geval zou moeten zijn of tijdens de mondelinge behandeling inhoudelijk meer is besproken dan reeds is neergelegd in de processtukken, maar ook wanneer het besprokene zal meewegen bij de beoordeling van de zaak. ${ }^{65}$ Andere gerechtvaardigde belangen zijn de wens van een partij om in een volgende instantie haar standpunt te kunnen onderbouwen met hetgeen tijdens de mondelinge behandeling is voorgevallen of met een concreet bewijsaanbod dat zij tijdens de zitting heeft gedaan. Bij het ontbreken van een proces-verbaal zal dergelijke informatie uitsluitend voorhanden zijn wanneer een partij schriftelijke aantekeningen in het geding heeft gebracht. ${ }^{66}$ De rechter kan in voornoemde gevallen ambtshalve of op verzoek van een partij een proces-verbaal opmaken. Daarnaast dient een proces-verbaal te worden opgemakt wanneer hiertoe een verzoek is gedaan door de rechter in hoger beroep of door de Hoge Raad. Art. 90 lid 1 Rv Spoedwet geldt niet voor verzoekschriftprocedures. Art. 279 lid $4 \mathrm{Rv}$ komt niet te vervallen, waardoor op grond van art. 279 lid 6 Rv Spoedwet de aard van de procedure zich verzet tegen toepassing van art. 90 lid $1 \mathrm{Rv}$ Spoedwet. Met art. 90 lid $1 \mathrm{Rv}$ Spoedwet vindt er dus slechts voor de dagvaardingsprocedure een wijziging plaats ten opzichte van de huidige praktijk. Art. 88 lid $3 \mathrm{Rv}$ bepaalt immers dat in geval van een inlichtingencomparitie altijd een proces-verbaal wordt gemaakt.

In art. 90 lid 2 en lid 5 Rv Spoedwet zijn de formele eisen neergelegd waaraan het proces-verbaal dient te voldoen. Zo dient het proces-verbaal de namen te bevatten van de behandelende rechter(s), de partijen en hun vertegenwoordigers en gemachtigden, maar ook de namen van getuigen en/of deskundigen en tolken, als deze op de mondelinge behandeling zijn verschenen. Voorts dient het proces-verbaal door de rechter te zijn ondertekend en bij verhindering van de rechter dient dit in het proces-verbaal te zijn vermeld.

In art. 90 lid 3 en $4 \mathrm{Rv}$ Spoedwet is neergelegd aan welke inhoudelijke eisen een proces-verbaal dient te voldoen. Allereerst is in art. 90 lid 3 Rv Spoedwet duidelijk bepaald dat het proces-verbaal een zakelijke samenvatting dient te bevatten van het verhandelde ter zitting. Het proces-verbaal is geen woordelijk verslag. ${ }^{67}$ Uit deze bepaling wordt afgeleid dat, anders dan nu veel in de praktijk geschiedt, niet kan worden volstaan met de algemene beschrijving dat de standpunten zijn toegelicht door partijen, partijen op elkaars standpunten hebben gereageerd en geen schikking tot stand is gekomen. In het proces-verbaal dient een samenvatting van de inhoud van het verhandelde ter zitting te worden opgenomen. ${ }^{68}$ Voor de vraag wat thuishoort in de zakelijke samenvatting kunnen de door De Groot geformuleerde vuistregels als uitgangspunt worden genomen: (1) het verhandelde is relevant voor de oordeelsvorming van de rechter; (2) het verhandelde is behulpzaam voor de aanvaardbaarheid van de uitspraak; en (3) het

64. Zie Kamerstukken II 2014/15, 34059, 3, p. 74.

65. Zie Steenberghe \& Den Tonkelaar 2017, p. 116

66. Zie De Groot 2019, p. 170-171.

67. Zie Kamerstukken II 2014/15, 34059, 3, p. 74

68. Zie Steenberghe \& Den Tonkelaar 2017, p. 116; De Groot 2019, p. 172. 
verhandelde kan betekenis hebben voor het partijdebat in de volgende instantie of de oordeelsvorming in de volgende instantie. ${ }^{69}$ Uit art. 90 lid 4 Rv Spoedwet volgt dat de rechter kan bepalen dat een verklaring van een partij, getuige en/of deskundige in het geheel in het proces-verbaal wordt opgenomen (ter onderscheiding van de zakelijke samenvatting). De tekst van art. 90 lid 4 Rv Spoedwet komt overeen met de tekst van art. $180 \mathrm{Rv}$ betreffende het proces-verbaal naar aanleiding van een getuigenverklaring. De verklaringen van de getuigen en/of deskundigen zijn in dit geval afgelegd tijdens de mondelinge behandeling op grond van art. 87 lid 3 Rv Spoedwet. Indien verklaringen tijdens de mondelinge behandeling zijn afgelegd, dient de verklaring onverwijld op schrift te worden gesteld en aan de partij, getuige of deskundige te worden voorgelegd. De partij mag dan nog wijzigingen aanbrengen die eveneens op schrift worden gesteld en aan de partij worden voorgelezen. Het proces-verbaal wordt in een dergelijk geval door de partij, getuige of deskundige ondertekend. Bij weigering van ondertekening wordt de reden van weigering vermeld. Door Steenberghe en Den Tonkelaar is de vraag gesteld wat de rechterlijke vrijheid betekent om een verklaring in het proces-verbaal op te nemen. Terecht merken zij op dat in dat geval het hierboven besproken criterium van art. 90 lid 1 onder a Rv Spoedwet richting geeft en dat de vrijheid van de rechter wordt beperkt wanneer een partij hierom verzoekt en hierbij belang heeft. ${ }^{70}$

De werkelijke procesvernieuwing die in de Wetgeving van 2016 in art. 30n lid 7 Rv KEI is geintroduceerd, te weten dat het proces-verbaal kan worden vervangen door een beeld- of geluidsopname, wordt eveneens met het Wetsvoorstel Spoedwet KEI ingevoerd. Deze mogelijkheid wordt neergelegd in art. 90 lid 7 Rv Spoedwet. De tekst van art. 90 lid 7 Rv Spoedwet geeft, evenals de tekst van art. 30n lid 7 Rv KEI, geen duidelijkheid over de inhoud van het proces-verbaal. De tekst lijkt te suggereren dat een beeld- of geluidsopname van de gehele zitting het schriftelijke proces-verbaal vervangt. ${ }^{71}$ Verdere verwarring op dit punt wordt veroorzaakt door de memorie van toelichting op art. 30n lid 7 Rv KEI, waar wordt gesproken van een opname van de zitting. ${ }^{72}$ In de nota van wijziging verduidelijkt de wetgever dat niet de opname van de gehele zitting het proces-verbaal vervangt, maar dat slechts een beeld- of geluidsopname van de zakelijke samenvatting van het verhandelde ter zitting het proces-verbaal vervangt. De opname die het proces-verbaal vervangt, is dus minder omvangrijk dan de opname van de gehele zitting. ${ }^{73}$ Dit betekent dat de rechter in plaats van het proces-verbaal aan de griffier te dicteren mondeling een zakelijke samenvatting geeft waarvan een beeld- of geluidsopname wordt gemaakt. De tijdswinst ten opzichte van het dicteren van een zakelijke samenvatting aan de griffier is

69. Zie De Groot 2019, p. 173.

70. Zie Steenberghe \& Den Tonkelaar 2017, p. 117.

71. Zie ook Van Mierlo \& Vonk 2015, p. 515.

72. Zie Kamerstukken II 2014/15, 34059, 3, p. 74. Zie ook Steenberghe \& Den Tonkelaar 2017, p. 117.

73. Zie Kamerstukken II 2014/15, 34059, 7, p. 9. dus beperkt. Wanneer de rechter een dergelijke opname maakt, is ondertekening niet nodig. ${ }^{74}$

Ook voor een ter zitting afgelegde verklaring van een getuige of deskundige geldt in beginsel dat niet een volledige beeld- of geluidsopname van het verhoor in de plaats treedt van het proces-verbaal, maar ook slechts een beeld- of geluidsopname van de zakelijke samenvatting. Dit zal anders zijn wanneer de rechter overeenkomstig art. 90 lid $4 \mathrm{Rv}$ Spoedwet heeft bepaald dat de gehele verklaring van een partij, getuige of deskundige in het proces-verbaal wordt opgenomen. Uit art. 90 lid $4 \mathrm{Rv}$ Spoedwet volgt dat een verklaring afkomstig van een partij, getuige of deskundige dient te worden ondertekend. Dit zou dan een digitale handtekening kunnen zijn, mits het gaat om een gekwalificeerde digitale handtekening als bedoeld in art. 3:15a BW. ${ }^{75}$ Zolang digitale ondertekening niet mogelijk is, zal een 'natte' handtekening moeten worden geplaatst, wat het onvermijdelijk maakt dat van de verklaring van een partij, getuige of deskundige een schriftelijk procesverbaal wordt opgemaakt. ${ }^{76} \mathrm{Om}$ deze procesvernieuwing werkelijk te laten plaatsvinden, is het dus van belang dat de rechtspraak digitale ondertekening technisch ook mogelijk maakt. Indien de rechter de zakelijke samenvatting heeft vastgelegd in een beeld- of geluidsopname kan de rechter in hoger beroep of de Hoge Raad de rechter verzoeken alsnog een schriftelijke weergave te geven. Deze schriftelijke weergave dient woordelijk gelijk te zijn aan de beeld- en geluidsopname van het proces-verbaal. ${ }^{77} \mathrm{Het}$ voorgaande laat onverlet dat de rechter wel kan besluiten om de gehele mondelinge behandeling of het verhoor van getuigen en/of deskundigen op te nemen, maar de rechter is hiertoe niet verplicht en de integrale opname geldt dus niet als een proces-verbaal. De integrale opname biedt alle betrokkenen een weergave van de zitting waar altijd op kan worden teruggevallen. Op deze beeld- of geluidsopname kan een partij zich ook in hoger beroep beroepen. ${ }^{78}$ Deze opname wordt opgenomen in het dossier. Indien een partij zich wil beroepen op de beeld- of geluidsopname dient zij wel aan te geven op welk onderdeel van de opname zij zich beroept. ${ }^{79}$ Een verbatim transcript kan in dat geval behulpzaam zijn, nu de partij die zich erop beroept, gehouden is aan te geven op welke passage zij een beroep doet (art. 22b Rv). ${ }^{80}$ De vraag of voor de integrale opname van een mondelinge behandeling toestemming is vereist, is niet beantwoord door de wetgever. ${ }^{81}$ Het ligt in de rede dat hiervoor de normale regels voor het maken van opnames gelden. ${ }^{82}$ Het verdient aanbeveling dat het procesreglement op dit punt in een regeling voorziet..$^{83}$

\footnotetext{
74. Zie Steenberghe \& Den Tonkelaar 2017, p. 117; De Groot 2019, p. 171.

75. Zie R.W.E. van Leuken, M.M.C. van de Moosdijk \& V. Tweehuysen, Hartkamps Compendium van het vermogensrecht, Deventer: Wolters Kluwer 2017, nr. 58.

76. Zie Steenberghe \& Den Tonkelaar 2017, p. 118.

77. Zie Kamerstukken II 2014/15, 34059, 7, p. 9.

78. Zie Kamerstukken II 2014/15, 34059, 6, p. 35.

79. Zie Kamerstukken II 2014/15, 34059, 7, p. 9 .

80. Zie Van Mierlo \& Vonk 2015, p. 515.

81. Zie Steenberghe \& Den Tonkelaar 2017, p. 118.

82. Zie De Groot 2019, p. 174.

83. Zie Steenberghe \& Den Tonkelaar 2017, p. 118.
} 
Met het Wetsvoorstel Spoedwet KEI is het slechts mogelijk om een beeld- of geluidsopname te maken van het verhoor van getuigen en/of deskundigen op de mondelinge behandeling. De mogelijkheid van een beeld- of geluidsopname ter vervanging van het proces-verbaal in art. 180 lid 1, art. 198 lid 5, art. 201 lid 4 en art. 90 lid 7 Rv KEI wordt met de Spoedwet KEI niet ingevoerd. Dit zal worden meegenomen bij de aanpassing van het bewijsrecht.

\section{Conclusie}

Op 26 maart 2019 is bij de Tweede Kamer het Wetsvoorstel Spoedwet KEI ingediend. Dit wetsvoorstel is een vervolg op de Wetgeving van 2016. Naast de intrekking van de verplichting tot digitaal procederen bij de rechtbanken Gelderland en Midden-Nederland worden met het Wetsvoorstel Spoedwet KEI ook enkele procesvernieuwingen van de Wetgeving van 2016 ingevoerd die zien op de regiefunctie van de rechter en de verruiming van de mogelijkheden tijdens de mondelinge behandeling. In deze bijdrage staan de wijzigingen rondom de regiefunctie van de rechter en de mondelinge behandeling centraal, waarbij een vergelijking is gemaakt met het huidige procesrecht om de vraag te beantwoorden of van werkelijke procesvernieuwingen sprake is. Sinds de wijziging van het Wetboek van Burgerlijke Rechtsvordering in 2002 en de opkomst van de comparitie na antwoord is immers de regiefunctie van de rechter rondom de mondelinge behandeling reeds versterkt. Deze lijn wordt verder doorgezet in het Wetsvoorstel Spoedwet KEI. Uit deze bijdrage volgt dat het Wetsvoorstel Spoedwet KEI deels een codificatie is van de in de praktijk ontwikkelde werkwijze en tracht uniformiteit aan te brengen. Voorts worden ook enkele procesvernieuwingen uit de Wetgeving van 2016 ingevoerd.

Uitgangspunt blijft ook onder het Wetsvoorstel Spoedwet KEI dat na de schriftelijke stukkenwisseling standaard een mondelinge behandeling plaatsvindt, die zo spoedig mogelijk na de schriftelijke stukkenwisseling door de rechter wordt bepaald (art. $131 \mathrm{Rv}$ Spoedwet). De doelen van de mondelinge behandeling zijn neergelegd in art. 87 lid $2 \mathrm{Rv}$ Spoedwet en stemmen grotendeels overeen met de huidige comparitie na antwoord. Een belangrijke wijziging ten opzichte van de huidige procespraktijk is dat het pleidooi ex art. $134 \mathrm{Rv}$ komt te vervallen. Tijdens de mondelinge behandeling ex art. $87 \mathrm{Rv}$ Spoedwet wordt echter aan partijen onder andere de mogelijkheid gegeven om hun stellingen toe te lichten (art. 87 lid $1 \mathrm{Rv}$ Spoedwet). Dit is geen discretionaire bevoegdheid van de rechter. Art. 87 lid $1 \mathrm{Rv}$ Spoedwet is imperatief geformuleerd, waardoor geen discussie bestaat over de vraag of partijen wel of niet de zaak mogen toelichten tijdens de mondelinge behandeling. Hiermee wordt een einde gemaakt aan de huidige onzekerheid of een partij de zaak mag 'bepleiten' bij de comparitie na antwoord ex art. $131 \mathrm{Rv}$. De rechter beschikt wel over vrijheid betreffende de verdere invulling van de mondelinge behandeling. In dit verband kan worden gedacht aan spreektijd, de te behandelen onderwerpen en het horen van getuigen en/of deskundigen op de mondelinge behandeling. De rechter wordt met art. 87 lid 4 Rv Spoedwet aangemoedigd om onder andere deze onderwerpen neer te leggen in een zogenaamde zittingsagenda, waarmee in de huidige praktijk slechts door sommige rechters wordt gewerkt, en hier standaardpraktijk van te maken. Om ook te voldoen aan het met de Wetgeving van 2016 en het Wetsvoorstel Spoedwet KEI beoogde maatwerk verdient het aanbeveling om de zittingsagenda zo veel mogelijk in overleg met partijen vast te stellen, en alvorens de mondelinge behandeling wordt bepaald partijen de gelegenheid te geven zich uit te laten over de invulling daarvan. Door op deze wijze met de zittingsagenda om te gaan wordt eveneens invulling gegeven aan de door de wetgever beoogde versterkte regierol van de rechter. Partijen kunnen uiterlijk tot tien dagen voor de mondelinge behandeling stukken indienen, zo volgt uit art. 87 lid 6 Rv Spoedwet. Art. 87 lid 6 Rv Spoedwet is een codificatie van de bestaande praktijk. De wetgever benadrukt in art. 87 lid $8 \mathrm{Rv}$ Spoedwet het recht op een mondelinge behandeling door te bepalen dat, wanneer geen mondelinge behandeling heeft plaatsgevonden, de rechter voordat hij over de zaak beslist, desverlangd aan partijen de gelegenheid geeft hun standpunt mondeling toe te lichten. De rechter hoeft partijen niet actief de wijzen op dit recht, maar wanneer een partij om een mondelinge behandeling verzoekt en deze heeft nog niet plaatsgevonden, dan dient dit verzoek te worden gehonoreerd.

Twee andere in het oog springende procesvernieuwingen zijn het horen onder ede van getuigen en deskundigen op de mondelinge behandeling (art. 87 lid 3 Rv Spoedwet) en de mogelijkheid dat het proces-verbaal wordt vervangen door een beeld- of geluidsopname (art. 90 lid 7 Rv Spoedwet). Ten aanzien van de beeld- of geluidsopname dient wel te worden opgemerkt dat niet de opname van de gehele zitting het proces-verbaal vervangt, maar dat slechts een beeld- of geluidsopname van de zakelijke samenvatting van het verhandelde ter zitting het proces-verbaal vervangt. Overigens kan wel een integrale opname van de mondelinge behandeling worden gemaakt waarop alle betrokkenen kunnen terugvallen. Voorts is een belangrijke wijziging dat de rechter niet gehouden is altijd een proces-verbaal van de zitting op te maken (art. 90 lid 1 Spoedwet KEI). 